Pathogenesis and toxins

\title{
Clostridium difficile infection among immunocompromised patients in Rio de Janeiro, Brazil and detection of moxifloxacin resistance in a ribotype 014 strain
}

\author{
Danielle Angst Secco ${ }^{\text {a, }}$, Ilana Teruszkin Balassiano ${ }^{\text {b }}$, Renata Ferreira Boente a, \\ Karla Rodrigues Miranda a , Jon Brazier ${ }^{c}$, Val Hall ${ }^{c}$, Joaquim dos Santos-Filho ${ }^{a}$, \\ Leandro Araujo Lobo ${ }^{a}$, Simone Aranha Nouér ${ }^{\mathrm{d}}$, \\ Regina Maria Cavalcanti Pilotto Domingues ${ }^{a}$ \\ ${ }^{a}$ Laboratório de Biologia de Anaeróbios, Departamento de Microbiologia Médica, Instituto de Microbiologia Prof. Paulo de Góes, \\ Centro de Ciências da Saúde, Universidade Federal do Rio de Janeiro, Av. Carlos Chagas Filho 373, CEP 21941-900 Rio de Janeiro, RJ, Brazil \\ ${ }^{\mathrm{b}}$ Laboratório de Zoonoses Bacterianas, Instituto Oswaldo Cruz-Fiocruz, Rio de Janeiro, RJ, Brazil

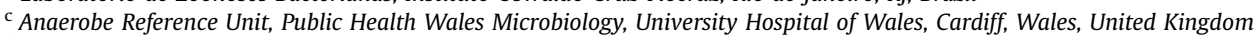 \\ ${ }^{\mathrm{d}}$ Coordenação de Controle de Infecções Hospitalares - HUCCF/UFRJ, Rio de Janeiro, RJ, Brazil
}

\section{A R T I C L E I N F O}

Article history:

Received 11 February 2014

Received in revised form

21 May 2014

Accepted 25 May 2014

Available online 5 June 2014

\section{Keywords:}

Clostridium difficile

CDI

Nosocomial infection

Moxifloxacin resistance

\begin{abstract}
A B S T R A C T
Clostridium difficile is a Gram-positive spore forming anaerobic bacterium, often associated with nosocomial diarrhea and pseudomembranous colitis. The acquisition of this organism occurs primarily in hospitals through accidental ingestion of spores, and its establishment and proliferation in the colon results from the removal of members of the normal intestinal flora during or after antibiotic therapy. In this study, stool samples from patients admitted to the University Hospital Clementino Fraga Filho (HUCCF/UFRJ) were screened for $C$. difficile toxins with an ELISA test and cultured with standard techniques for $C$. difficile isolation. A total of 74 stool samples were collected from patients undergoing antibiotic therapy between August 2009 and November 2010, only two (2.7\%) were positive in the ELISA test and culture. A third isolate was obtained from a negative ELISA test sample. All cases of CDI were identified in patients with acute lymphoid or myeloid leukemia. Genotypic and phenotypic characterization showed that all strains carried toxins A and B genes, and belonged to PCR-ribotypes 014,043 and 046. The isolated strains were sensitive to metronidazole and vancomycin, and resistant to ciprofloxacin and levofloxacin. Resistance to moxifloxacin, was present in the strain from PCR-ribotype 014, that showed an amino acid substitution in gyrB gene (Asp $426 \rightarrow$ Asn). This is the first time that this mutation in a PCR-ribotype 014 strain has been described in Brazil.
\end{abstract}

(C) 2014 Elsevier Ltd. All rights reserved.

\section{Introduction}

Clostridium difficile is a Gram-positive spore forming anaerobic bacterium. C. difficile infection (CDI) is highly prevalent in hospitals and is the most common cause of nosocomial diarrhea in adults, mainly in elderly and immunocompromised patients $[1,2]$. CDI cases in solid organ transplant recipients, hematopoietic stem cell or bone marrow transplant recipients and HIV-seropositive individuals are reported to be higher in units caring for these patients [3].

\footnotetext{
* Corresponding author. Tel.: +55 2125608344 .

E-mail address: daniangstsecco@gmail.com (D.A. Secco).
}

Proliferation of $C$. difficile in the colon results from the removal of members of the normal intestinal flora in consequence of antibiotic therapy $[4,5]$. Practically any antibiotic can be associated with CDI, but the antibiotics most commonly associated are clindamycin, cephalosporins and penicillins [6,7]. However, many studies have also described a high association between fluoroquinolones use and CDI, that may be related, even in part, to the development of fluoroquinolones resistance among $C$. difficile isolates in the last years [8-12].

C. difficile pathogenic strains are able to produce two toxins, enterotoxin $A(\operatorname{Tcd} A)$ and cytotoxin $B(T c d B)$, which constitute the major virulence factors of this species [7]. These toxins elicit several effects on the host, such as chemokine and cytokine production, 
neutrophil infiltration, mast cell activation, disruption of the tight junctions and actin depolymerization that lead to an extended inflammatory process [13]. In addition to toxins A and B, some strains produce $C$. difficile binary toxin (CDT), that is encoded by $c d t A$ and $c d t B$ genes [14]. The role of CDT in disease is not well understood, but it seems to potentiate the toxicity of the toxins A and $\mathrm{B}[7,15]$.

In the past decade a hypervirulent epidemic strain, classified as PCR-ribotype 027, has emerged and has been involved in more severe $C$. difficile associated diarrhea outbreaks in the United States, Canada, UK and other European countries [7,8,16-20]. This strain is resistant to fluoroquinolones, has deletions in $t c d C$ gene that seem to be related to an overproduction of $A$ and $B$ toxins, produces binary toxin, shows alterations in surface layer protein A (SlpA) associated with an increased adherence to human intestinal cells and has increased sporulation rates, which contribute to its spread and survival at the hospital environment [7,15,21,22]. In Brazil, the detection of this hypervirulent strain has not been reported to date.

Fluoroquinolones are a broad-spectrum antibiotic class, which has been strongly associated to CDI [23]. This class of drug has favorable pharmacokinetic properties that have encouraged their widespread use. They have good tissue penetration and are well absorbed when taken orally, which facilitates their use for treatment of many diseases [24]. C. difficile isolates resistant to moxifloxacin, a fourth-generation fluoroquinolone, have one or more single nucleotide point mutation within the quinolone resistancedetermining regions (QRDR) of their DNA gyrase genes. At least seven mutations within the QRDR of gyrA and seven more in gyrB of C. difficile are known to occur $[25,26]$. The most frequent amino acid change is Thr82 $\rightarrow$ Ile in gyrA, which is also present in the hypervirulent PCR-ribotype 027 strain [27]. A study conducted in South Korea showed that the use of fluoroquinolones was highly related to resistance to moxifloxacin in $C$. difficile strains [28]. In the past decades, CDI has increased in number of cases and rates of mortality and morbidity, associated in part to the emergence of the PCR-ribotype 027 strain in many countries. It has been hypothesized that fluoroquinolone-resistance may have facilitated spread of this strain potentially providing it a survival advantage in the hospital environments where fluoroquinolones are extensively used [29,30].

In Brazil, there are few studies addressing the role of $C$. difficile as an agent of nosocomial diarrhea, as well as their incidence and spread $[2,31-34]$. Thus, the aim of this study was to isolate and characterize genotypically and phenotypically $C$. difficile strains from fecal samples of inpatients of a university hospital in Rio de Janeiro, Brazil.

\section{Materials and methods}

\subsection{Fecal isolates}

Seventy-four fecal samples were obtained and analyzed between August 2009 and November 2010 from inpatients admitted in 15 different wards of "Hospital Universitário Clementino Fraga Filho (HUCFF)", affiliated to "Universidade Federal do Rio de Janeiro (UFRJ)" in Brazil. All patients were under broad-spectrum antibiotic therapy and the samples were collected during active diarrhea episodes. All samples were tested for the presence of toxins A and B by Ridascreen $C$. difficile Toxin A/B (R-Biopharm) ${ }^{\circledR}$ enzimatic assay (ELISA), according to manufacturer's instructions.

Stool samples were also cultured using the standardized process of isolation and identification [35]. Faecal samples were cultured directly or after an enrichment step (alcohol shock procedure) onto selective cycloserine/cefoxitin/fructose agar (CCFA). The plates were incubated anaerobically at $37{ }^{\circ} \mathrm{C}$ for $48 \mathrm{~h}$. C. difficile isolates were identified based on morphology characteristics of this species in
CCFA plates, Gram staining and characteristic odor. Isolates were confirmed as $C$. difficile by polymerase chain reaction (PCR) targeting tpi gene, a species-specific triose phosphate isomerase gene [36].

\subsection{Toxigenic profile of the isolates}

PCR for detecting the $t c d A$ [36], $t c d B$ [33], $c d t A$ and $c d t B$ [37] genes was performed as previously described. Amplification and sequencing of $t c d C$ [38] was also performed to investigate deletions in this gene and the sequences were analyzed using the BLAST server of National Center for Biotechnology Information (NCBI).

\subsection{PCR-ribotyping}

C. difficile isolates were analyzed at the Anaerobe Reference Laboratory by PCR-ribotyping as previously described [39]. Gel images were analyzed using Gel Compar II Software (version 4.0; Applied Maths, Kortrijk, Belgium).

\subsection{Minimal inhibitory concentration determination}

MICs for clindamycin (CLI), metronidazole (MTZ), vancomicyn (VAN), moxifloxacin (MX), levofloxacin (LX) and ciprofloxacin (CIP) were determined for each $C$. difficile isolate by using E-test strips (AB Biodisk), according to the manufacturer's instructions. Quality control strains (Bacteroides fragilis ATCC 25285 and Staphylococcus aureus ATCC 29213) were used. The breakpoints for CLI ( $\geq 8 \mathrm{mg} / \mathrm{L})$ and MTZ ( $\geq 8 \mathrm{mg} / \mathrm{L}$ ) were determined in accord to CLSI guidelines (2007). For antibiotics, for which no standard breakpoints have been defined, breakpoints were considered as follows: VAN $\geq 8 \mathrm{mg}$ / L, MX $\geq 4 \mathrm{mg} / \mathrm{L}, \mathrm{LX} \geq 4 \mathrm{mg} / \mathrm{L}, \mathrm{CIP} \geq 8 \mathrm{mg} / \mathrm{L}[27,40]$.

\subsection{Detection of mutation in resistance genes}

A quinolone resistance-determining region (QRDR) of DNA gyrase genes gyrA and gyrB [25] was amplified by PCR and the resulting amplicons were purified (GFX PCR DNA \& Gel Band ${ }^{\circledR}$ (GE Healthcare)) and sequenced. The amino acid sequence alignments from $C$. difficile strain 630 were produced for comparison, whose sequences are available at NCBI databank.

\section{Results}

The seventy four stool samples obtained from patients of HUCFF were cultured and tested for the presence of toxins A and B by ELISA to detect active $\mathrm{CDI}$ (characterized as the detection of toxins and/or presence of the microorganism). Three samples obtained a positive result using an ELISA commercial assay, and $C$. difficile could be recovered from two of these samples. Besides that, $C$. difficile was also isolated from a sample that had a negative result in ELISA, presenting a total of four cases of CDI during the study. All cases of CDI were identified in patients from the hematology ward. These patients had acute lymphoid or myeloid leukemia and had made use of antimicrobial agents and chemotherapy. Table 1 shows the clinical information of the four patients.

Detection of $t c d A$ and $t c d B$ genes by PCR confirmed that all strains were toxigenic. The genes of CDT ( $c d t A$ and $c d t B)$ were not detected, and no deletions in $t c d C$ genes from the isolates were observed. PCR-ribotypes 014 [isolate DHU 22 (A)], 043 [DHU 3 (A)] and 046 [DHU 5] were identified among the isolates. PCR-ribotype 027 was not detected.

All strains were sensitive to metronidazole and vancomycin, but resistant to the fluoroquinolones ciprofloxacin and levofloxacin. Resistance to moxifloxacin, a fourth-generation fluoroquinolone, was demonstrated only in DHU 22 (A) strain, from PCR-ribotype 
Table 1

Characterization of CDI patients from "Hospital Universitário Clementino Fraga Filho - HUCFF".

\begin{tabular}{|c|c|c|c|c|c|c|}
\hline Patient identification & Clinical conditions & Age (gender) & Chemotherapy & Antibiotics & AHSCT $^{\mathrm{m}}$ & Period \\
\hline DHU 3 & $\mathrm{AML}^{\mathrm{a}}$ & $33(\mathrm{M})$ & + & TRI $^{\mathrm{c}} ; \mathrm{IMI}^{\mathrm{d}} ; \mathrm{VAN}^{\mathrm{e}} ; \mathrm{POL}^{\mathrm{f}} ; \mathrm{AMP}^{\mathrm{g}} ; \mathrm{MTZ}^{\mathrm{h}}$ & + & August/2009 \\
\hline DHU 5 & AML & $44(\mathrm{M})$ & + & $\mathrm{CEF}^{\mathrm{i}} ; \mathrm{IMI} ; \mathrm{TEI}^{\mathrm{j}} ; \mathrm{CIP}^{\mathrm{k}}$ & + & September/2009 \\
\hline DHU 22 & $\mathrm{ALL}^{\mathrm{b}}$ & $33(\mathrm{~F})$ & + & TRI; MER ${ }^{1}$ & - & December/2009 \\
\hline DHU 50 & AML & $34(\mathrm{M})$ & + & CEF; MTZ; TRI, IMI & + & July/2010 \\
\hline
\end{tabular}

aML: Acute myeloid leukemia

b ALL: Acute lymphoblastic leukemia.

c TRI : Trimetropim.

d IMI: Imipenem.

e VAN: Vancomicin.

f POL: Polimixin.

g AMP: Ampicilin.

h MTZ: Metronidazole.

i CEF: Cefepime.

j TEI: Teicoplanin.

k CIP: Ciprofloxacin.

1 MER: Meropenem.

m AHSCT: Allogeneic hematopoietic stem cell transplantation.

014. Only one isolate [DHU3 (A)] was sensitive to clindamicyn (Table 2).

After sequencing of QRDR regions of gyrA and gyrB genes, an analysis of the sequence translation demonstrated an amino acid substitution in gyrB of the isolate from PCR-ribotype 014. This substitution led to a codon change, from GAT to AAT, which resulted on the substitution of the amino acid aspartic acid (Asp) to asparagine (Asn), at position 426 (Asp $426 \rightarrow$ Asn).

\section{Discussion}

In recent years, Cdifficile infection has gained importance due to the greater frequency and severity of cases and is considered the main etiological agent of cases of diarrhea associated with antibiotics [41,42]. In Brazil, there is limited information about the infection promoted by $C$. difficile, especially regarding the incidence of CDI, dissemination of the pathogen in hospitals and its resistance to various antibiotics. This lack of information seems to be directly related to limited technologies of national laboratories available to investigate this organism, leading to underreporting of CDI cases [2]. Although our work used a small number of samples, the presence of CDI was detected in 5.4\% (4/74) of patients under broadspectrum antibiotic therapy enrolled in this study, and $C$. difficile could be recovered from 3 of the stool samples from these patients. The other ELISA-positive sample was repeatedly subjected to culture, but we were not able to recover $C$. difficile. All cases of CDI in this study were detected in patients with acute myeloid ( 3 out of 4 patients with this disease in the study) or lymphoblastic leukemia ( 1 out of 2). Patients with hematologic diseases are very susceptible to $\mathrm{CDI}$ as most of them present a combination of risk factors for CDI such as bone narrow and peripheral blood stem cell transplantation, recent receipt of chemotherapy and use of antimicrobial agents [43-45].

Table 2

MIC value (mg/L) obtained for the $C$. difficile strains from HUCFF.

\begin{tabular}{lllllll}
\hline MIC $(\mathrm{mg} / \mathrm{L})$ & \multicolumn{7}{l}{} \\
\hline Strain & MTZ & VAN & CLI & CIP & LX & MX \\
\hline DHU 3 (A) & 0.5 & 2.0 & 4.0 & $\geq 32.0$ & $\mathbf{1 6 . 0}$ & 1.0 \\
DHU 5 & 0.25 & 2.0 & $\mathbf{1 6 . 0}$ & $\geq \mathbf{3 2 . 0}$ & $\mathbf{1 6 . 0}$ & 2.0 \\
DHU 22 (A) & 0.25 & 1.0 & $\mathbf{8 . 0}$ & $\geq \mathbf{3 2 . 0}$ & $\geq \mathbf{3 2 . 0}$ & $\geq \mathbf{3 2 . 0}$ \\
\hline
\end{tabular}

Breakpoints: MTZ - metronidazole (breakpoint $\geq 8 \mathrm{mg} / \mathrm{L}$ ); VAN - vancomycin (breakpoint $\geq 8 \mathrm{mg} / \mathrm{L}$ ); CLI - clindamycin (breakpoint $\geq 8 \mathrm{mg} / \mathrm{L}$ ); CIP - ciprofloxacin (breakpoint $\geq 8 \mathrm{mg} / \mathrm{L}$ ); LX - levofloxacin (breakpoint $\geq 4 \mathrm{mg} / \mathrm{L}$ ); $\mathrm{MX}-$ moxifloxacin (breakpoint $\geq 4 \mathrm{mg} / \mathrm{L}$ ); MICs greater or equal to breakpoint are in bold.
The culture of diarrheal feces for isolation of $C$. difficile is not performed routinely in the clinic, even though the combination of a $\mathrm{CDI}$ diagnosis based on toxin detection and the culture and isolation of $C$. difficile is considered the most accurate methodology for the diagnosis of CDI [2]. Culture is extremely useful because it allows the realization of further typing of strains and epidemiological studies [6]. A commonly used typing methodology is PCRribotyping, which is high discriminative, reproducible, relatively rapid and easy to perform [39]. Our PCR-ribotyping analysis revealed the presence of three distinct PCR-ribotypes, 014, 043 and 046. The hypervirulent strain belonging to PCR-ribotype 027, was not found in these samples, and considering the works published in the country so far, this PCR-ribotype is not yet in circulation in Brazil $[2,31-34,46-50]$.

The PCR-ribotypes 043 and 046 are more rarely found than PCRribotype 014. These two PCR-ribotypes had been described in Brazil many years ago by Alcides et al. [32], in a study conducted at a public children's hospital "Instituto de Puericultura e Pediatria Martagão Gesteira (IPPMG)", a HUCFF neighboring building.

The PCR-ribotype 014 is widely distributed throughout the world and it has been reported in almost all European countries [51,52]. The PCR-ribotype 014 has been also described in Brazil, by Balassiano et al., in 2009 [33], when strains were isolated from feces of hospitalized patients between 2006 and 2007 at "Instituto de Pesquisa Clínica Evandro Chagas - IPEC", located at "Fundação Oswaldo Cruz", also in Rio de Janeiro. The isolation of a strain of this PCR-ribotype in HUCFF could suggest a spread of $C$. difficile between hospitals and medical centers, which reinforces the need of more surveillance studies to monitoring this important pathogen.

The three isolates were sensitive to metronidazole and vancomycin, drugs used to treat the disease. This was expected since reports of resistance to these drugs are extremely rare [27]. Resistance to clindamycin is common among strains related to outbreaks, but among the non-epidemic strains, high levels of resistance (MIC $>256 \mathrm{mg} / \mathrm{ml}$ ) are found in only $10 \%$ [53]. All strains in this study had low to moderate resistance (MIC $4-8 \mathrm{mg} / \mathrm{ml}$ ) to this antibiotic. Currently, fluoroquinolone-resistance characterizes not only the epidemic $C$. difficile strain PCR-ribotype 027, but also other types of strains, epidemic or not [26,54]. Several studies have associated this resistance with an increase of virulence potential $[16,18]$. A case-control study conducted in 2003 found an association between fluoroquinolones and CDI stronger than the association between clindamycin and this disease [9]. In this study all strains were resistant to ciprofloxacin and to another second generation fluoroquinolone, levofloxacin. These results are in 
agreement with those obtained by several research groups $[2,27,33,34,37,55]$. Resistance to moxifloxacin, a fourth-generation fluoroquinolone, is a hallmark of PCR-ribotype 027, also present in other multi-resistant strains of $C$. difficile. In this study, only the strain belonging to PCR-ribotype 014 was resistant to this antibiotic. When this PCR-ribotype was first isolated in Brazil by Balassiano et al. [33] in a study conducted between 2006 and 2007 in IPEC, this strain was susceptible to moxifloxacin.

To investigate the molecular mechanisms associated with fluoroquinolone-resistance regions of the genes that encode the subunits of DNA gyrase (gyrA and gyrB genes) were analyzed. So far, at least seven different amino acid substitutions in the gyrA gene and seven other in gyrB gene have been described, principally conferring resistance to moxifloxacin [27,56]. Mutations in gyrA occur more frequently than those observed in $\operatorname{gyr} B$ and $\mathrm{Thr}_{82} \rightarrow$ Ile in gyrA is the most common replacement in fluoroquinolone resistant strains [57]. Despite all isolated strains being resistant to ciprofloxacin and levofloxacin, only the DHU 22 (A) isolate, belonging to PCR-ribotype 014, was resistant to moxifloxacin with an MIC of $\geq 32 \mathrm{mg} / \mathrm{L}$, which indicates a high level of resistance to this drug. This strain was also the only one to demonstrate an amino acid substitution, the exchange $\mathrm{Asp}_{426} \rightarrow$ Asn in gyrB. This type of mutation is usually associated with low and intermediate levels of resistance to moxifloxacin, while high levels of resistance are mainly related to the substitution Thr82 $\rightarrow$ Ile in gyrA [27]. Resistance to moxifloxacin in C. difficile PCR-ribotype 014 as well as the point mutation (Asp $426 \rightarrow$ Asn) has been described previously by Spigaglia et al., in 2010 [57]. However, this is the first report of this mutation in a PCR-ribotype 014 strain in Brazil. Since moxifloxacin resistance may be regarded as an important factor in $C$. difficile spread, aided by such indiscriminate use of this antibiotic, the fact that we have isolated a PCR-ribotype 014 strain showing moxifloxacin resistance only three years after the first report of this PCRribotype in the country, which at that time were sensitive to moxifloxacin, may suggest that resistance to fluoroquinolones could be contributing to permanence, survival and prevalence of certain clones of $C$. difficile in the hospital environment.

\section{Acknowledgments}

This work was supported by the following national institutions: CAPES, CNPq, FAPERJ, PRONEX.

\section{References}

[1] Bujanda L, Cosme A. Diarrea asociada a Clostridium difficile. Gastroenterol Hepatol 2009;32(1):48-56.

[2] Balassiano IT, Santos-Filho J, Vital-Brazil JM, Nouér SA, Souza CT, Brazier JS, et al. Detection of cross-infection associated to a Brazilian PCR-ribotype of Clostridium difficile in a university hospital in Rio de Janeiro, Brasil. Antonie van Leeuwenhoek 2011;99(2):249-55.

[3] Collini PJ, Bauer M, Kuijper E, Dockrell DH. Clostridium difficile infection in HIV-seropositive individuals and transplant recipients. J Infect 2012;64: $131-47$.

[4] Chang JY, Antonopoulos DA, Kalra A, Tonelli A, Khalife W, Schmidt TM, et al. Decreased diversity of the fecal microbiome in recurrent Clostridium difficileassociated diarrhea. J Infect Dis 2008;197:435-8.

[5] Britton RA, Young VB. Interaction between the intestinal microbiota and host in Clostridium difficile colonization resistance. Trends Microbiol 2012;20(7): 313-9.

[6] Schroeder MS. Clostridium difficile-associated diarrhea. Am Fam Physician 2005; 71(5):921-8.

[7] Rupnik M, Wilcox MH, Gerding DN. Clostridium difficile infection: new developments in epidemiology and pathogenesis. Nat Rev Microbiol 2009;7: $526-36$.

[8] Loo VG, Poirier L, Miller MA, Oughton M, Libman MD, Michaud S, et al. A predominantly clonal multi-institutional outbreak of Clostridium difficileassociated diarrhea with high morbity and mortality. N Engl J Med 2005;353(23):2442-9.
[9] McCusker ME, Harris AD, Perencevich E, Roghmann MC. Fluoroquinolone use and Clostridium difficile-associated diarrhea. Emerg Infect Dis 2003;9(6): 730-3.

[10] Owens RC, Donskey CJ, Gaynes RP, Loo VG, Muto CA. Antimicrobial-associated risk factors for Clostridium difficile infection. Clin Infect Dis 2008;46(Suppl. 1): S19-31.

[11] Pépin J, Saheb N, Coulombe MA, Alary ME, Corriveau MP, Authier S. Emergence of fluoroquinolones as the predominant risk factor for Clostridium difficile-associated diarrhea: a cohort study during an epidemic in Quebec. Clin Infect Dis 2005;41:1254-60.

[12] Walkty A, Boyd DA, Gravel D, Hutchinson J, McGeers A, Moore D, et al. Molecular characterization of moxifloxacin resistance from Canadian Clostridium difficile clinical isolates. Diagn Microbiol Infect Dis 2010;66(4):419-24.

[13] Voth DE, Ballard JD. Clostridium difficile toxins: mechanism of action and role in disease. Clin Microbiol Rev 2005;18:247-63.

[14] Carter GP, Lyras D, Allen DL, Mackin KE, Howarth PM, O'connor JR, et al. Binary toxin production in Clostridium difficile is regulated by CdtR, a LytTR family response regulator. J Bacteriol 2007;189(20):7290-301.

[15] Barbut F, Decre D, Lalande V, Burghoffer B, Noussair L, Gigandon A. Clinical features of Clostridium difficile associated diarrhoea due to binary toxin producing strains. J Med Microbiol 2005;54:181-5.

[16] McDonald LC, Killgore GE, Thompson A, Owens RCJ, Kazakova SV, Sambol SP et al. An epidemic, toxin gene-variant strain of Clostridium difficile. N Engl J Med 2005;353(23):2433-41.

[17] Warny M, Pepin J, Fang A, Killgore G, Thompson A, Brazier J, et al. Toxin production by an emerging strain of Clostridium difficile associated with outbreaks of severe disease in North America and Europe. Lancet 2005;366: $1079-84$.

[18] MacCannel DR, Louie TJ, Gregson DB, Laverdiere M, Labbe AC, Laing F, et al Molecular analysis of Clostridium difficile PCR ribotype 027 isolates from Eastern and Western Canada. J Clin Microbiol 2006;44(6):2147-52.

[19] Labbé AC, Poirier L, Maccannel D, Louie T, Savoie M, Béliveau C, et al. Clostridium difficile infections in a Canadian tertiary care hospital before and during a regional epidemic associated with the BI/NAP1/027 strain. Antimicrobial Agents Chemother 2008;52(9):3180-7.

[20] Kuijper EJ, Coignard B, Tull P. Emergence of Clostridium difficile-associated disease in North America and Europe. Clin Microbiol Infect 2008;12(Suppl. 6): $2-18$.

[21] Stabler RA, Dawson LF, Phua LT, Wren BW. Comparative analysis of BI/NAP1/ 027 hypervirulent strains reveals novel toxin B-enconding gene (tcdB) sequences. J Med Microbiol 2009;57(6):771-5.

[22] Akerlund T, Persson I, Unemo M, Noren T, Svenungsson B, Wullt M. Increased sporulation rate of epidemic Clostridium difficile Type 027/NAP1. J Clin Microbiol 2008;46:1530-3.

[23] Muto CA, Pokrywka M, Shutt K, Mendelsohn AB, Nouri K, Posey K, et al. A large outbreak of Clostridium difficile-associated disease with an unexpected proportion of deaths and colectomies at a teaching hospital following increased fluoroquinolone use. Infect Control Hosp Epidemiol 2005;26:273-80.

[24] O'Donnell JA, Gelone SP. The newer fluoroquinolones. Infect Dis Clin North Am 2004; $18(3): 691-716$.

[25] Dridi L, Tankovic J, Burghoffer B, Barbut F, Petit JC. gyrA and gyrB mutations are implicated in cross-resistance to ciprofloxacin and moxifloxacin in Clostridium difficile. Antimicrobial Agents Chemother 2002;46:3418-21.

[26] Spigaglia P, Barbanti F, Mastrantonio P, Brazier JS, Barbut F, Delmée M. Fluoroquinolone resistance in Clostridium difficile isolates from a prospectivestudy of C. difficile infections in Europe. J Med Microbiol 2008;57: 784-9.

[27] Huang H, Weintraub A, Fang H, Nord CE. Antimicrobial resistance in Clostridium difficile. Int J Antimicrob Agents 2009;34:516-22.

[28] Kim J, Kang JO, Pai H, Choi TY. Association between PCR ribotypes and antimicrobial susceptibility among Clostridium difficile isolates from healthcareassociated infections in South Korea. Int J Antimicrob Agents 2012;40(1): 24-9.

[29] Kelly CP, Lamont JT. Clostridium difficile - more difficult that ever. N Engl . Med 2008:359:1932-40.

[30] Kee VR. Clostridium difficile infection in older adults: a review and update on its management. Am J Geriatr Pharmacother 2012;10(1):14-24.

[31] Pinto LJF, Alcides APP, Ferreira EO, Avelar KES, Sabrá A, Domingues RMCP et al. Incidence and importance of Clostridium difficile in paediatric diarrhoea in Brazil. J Med Microbiol 2003;52:1095-9.

[32] Alcides AP, Brazier JS, Pinto LJ, Balassiano IT, Boente RF, de Paula GR, et al. New PCR ribotypes of Clostridium difficile detected in children in Brazil: prevalent types of Clostridium difficile in Brazil. Antonie van Leeuwenhoek 2007;92(1): 53-9.

[33] Balassiano IT, Miranda KR, Boente RF, Pauer H, Oliveira IC, Santos-Filho J, et al Characterization of Clostridium difficile strains isolated from immunosuppressed inpatients in a hospital in Rio de Janeiro, Brazil. Anaerobe 2009;15(3): $61-4$.

[34] Balassiano IT, Santos-Filho J, Oliveira MPB, Ramos MC, Japiassu AM, Reis AM, et al. An outbreak case of Clostridium difficile-associated diarrhea among elderly inpatientes of an intensive care unit of a tertiary hospital in Rio de Janeiro, Brazil. Diagn Microbiol Infect Dis 2010;68:449-55.

[35] Jousimies-Somer HR, Summanen P, Citron DM, Baron EJ, Wexler HM, Finegold SM. Anaerobic bacteriology manual. $6^{\text {th }}$ ed. Belmont, CA: Star Publishing Company; 2002. 
[36] Lemee L, Dhalluin A, Pestel-Carol M, Lemeland JF, Pons JL. Multilocus sequence typing analysis of human and animal Clostridium difficile isolates of various toxigenic types. J Clin Microbiol 2004;42(6):2609-17.

[37] Barbut F, Mastrantonio P, Delmée M, Brazier J, Kuijper E, Poxton I. European study group on Clostridium difficile (ESGCD). Prospective study of Clostridium difficile infections in Europe with phenotypic and genotypic characterisation of the isolates. Clin Microbiol Infect 2007;13:1048-57.

[38] Spigaglia P, Mastrantonio P. Comparative analysis of Clostridium difficile clinical isolates belonging to different genetic lineages and time periods. J Med Microbiol 2004;53:1129-36.

[39] Stubbs SLJ, Brazier JS, O'Neil GL, Duerden BI. PCR targeted to the 16S-23S rRNA gene intergenic spacer region of Clostridium difficile and construction of a library consisting of 116 different PCR ribotypes. J Clin Microbiol 1999;37: 461-3.

[40] Mutlu E, Wroe AJ, Sanchez-Hurtado K, Brazier JS, Poxton IR. Molecular characterization and antimicrobial susceptibility patterns of Clostridium difficile strains isolated from hospitals in south-east Scotland. J Med Microbiol 2007; 56:921-9.

[41] Hookman P, Barkin JS. Clostridium difficile associated infection, diarrhea and colitis. World J Gastroenterol 2009:15(13):1554-80.

[42] Freeman J, Bauer MP, Baines SD, Corver J, Fawley WN, Goorhuis B, et al. The changing epidemiology of Clostridium difficile infections. Clin Microbiol Rev 2010;23(3):529-49.

[43] Dettenkofer M, Ebner W, Bertz H, Babikir R, Finke J, Frank U, et al. Surveillance of nosocomial infections in adult recipients of allogeneic and autologous bone marrow and peripheral blood stem-cell transplantation. Bone Marrow Transplant 2003;31:795-801.

[44] Schalk E, Bohr URM, Konig B, Scheinpflug K, Mohren M. Clostridium difficile associated diarrhea, a frequente complication in patients with acute myeloid leukaemia. Ann Hematol 2010:89:9-14.

[45] Apostolopoulou E, Raftopoulos V, Terzis K, Elefsiniotis I. Infection probability score: a predictor of Clostridium difficile-associated disease onset in patients with haematological malignancy. Eur J Oncol Nurs 2011;15(5):404-9.

[46] Garcia LB, Uzeda M. Ocurrence of Clostridium difficile in the feces of children of Rio de Janeiro, RJ, Brazil. Rev Inst Med Trop São Paulo 1988;30(6):419-23.
[47] Ferreira CE, Nakano V, Durigon EL, Avila-Campos MJ. Prevalence of Clostridium spp. and Clostridium difficile in children with acute diarrhea in São Paulo city, Brazil. Mem Inst Oswaldo Cruz 2003;98(4):451-4.

[48] Marcon AP, Gamba MA, Vianna LA. Nosocomial diarrhea in the intensive care unit. Braz J Infect Dis 2006;10(6):384-9.

[49] Marra AR, Edmond MB, Wenzel RP, Bearman GM. Hospital-acquired Clostridium difficile-associated disease in the intensive care unit setting: epidemiology, clinical course and outcome. BMC Infect Dis 2007;7:42.

[50] Souza-Dias MM, Yamashiro J, Borrasca VL, Stempliuk VA, Araujo MR, Costa SF, et al. Pseudo-outbreak of Clostridium difficile associated diarrhea (CDAD) in a tertiary-care hospital. Rev Inst Med Trop São Paulo 2010;52(3):133-7.

[51] Huang H, Weintraub A, Fang H, Wu S, Zhang Y, Nord CE. Antimicrobial susceptibility and heteroresistance in Chinese Clostridium difficile strains. Anaerobe 2010;16:633-5.

[52] Bauer MP, Notermans DW, Benthem BHB, Brazier JS, Wilcox MH, Rupnik M, et al. Clostridium difficile infection in Europe: a hospital-based survey. Lancet 2011;377:63-73.

[53] Aspevall O, Lundberg A, Burman LG, Akerlund T, Svenungsson B. Antimicrobial susceptibility pattern of Clostridium difficile and its relation to PCR ribotypes in a Swedish University Hospital. Antimicrobial Agents Chemother 2006;50: 1890-2.

[54] Drudy D, Fanning S, Kyne L. Toxin A-negative, toxin B-positive Clostridium difficile. Int J Infect Dis 2007;11:5-10.

[55] Bourgault AM, Lamothe F, Loo VG, Poirier L. CDAD-CSI study group. In vitro susceptibility of Clostridium difficile clinical isolates from a multiinstitutional outbreak in Southern Québec, Canada. Antimicrobial Agents Chemother 2006;50:3473-5.

[56] Carman RJ, Genheimer CW, Rafii F, Park M, Hiltonsmith MF, Lyerly DM. Diversity of moxifloxacin resistance during a nosocomial outbreak of a predominantly ribotype ARU 027 Clostridium difficile diarrhea. Anaerobe 2009; $15: 244-8$.

[57] Spigaglia P, Carattoli A, Barbanti F, Mastrantonio P. Detection of gyrA and gyrB mutations in Clostridium difficile isolates by real-time PCR. Mol Cell Probes 2010;24(2):61-7. 